\title{
Towards navigational safety of ecosystem based Maritime Spatial Planning solutions
}

\author{
Mihhail Fetissov ${ }^{1,2}$, Robert Aps ${ }^{1}$, Kaidi Katus $^{3}$, Anni Konsap ${ }^{4}$, Liisi Lees ${ }^{1}$, Nele Kristin \\ Meyer $^{5}$, Anneliis Peterson ${ }^{1}$, Olev Tõnismaa ${ }^{2}$ and Riku Varjopuro ${ }^{6}$ \\ ${ }^{1}$ University of Tartu, Estonian Marine Institute, Tallinn, Estonia \\ ${ }^{2}$ Tallinn University of Technology, Estonian Maritime Academy, Tallinn, Estonia \\ ${ }^{3}$ Estonian Maritime Administration, Tallinn, Estonia \\ ${ }^{4}$ Ministry of Finance, Spatial Planning Department, Tallinn, Estonia \\ ${ }^{5}$ Federal Maritime and Hydrographic Agency, Hamburg, Germany \\ ${ }^{6}$ Finnish Environment Institute, Helsinki, Finland
}

\begin{abstract}
According to EU Directive establishing a framework for Maritime Spatial Planning (MSP) the main purpose of MSP is to promote sustainable development and to identify the utilization of maritime space for different sea uses as well as to manage spatial uses and conflicts in marine areas. The offshore wind energy production is considered to be one of the main drivers of MSP in the Baltic Sea Region. However, the impact on navigational safety from offshore renewable energy installations (OREI) should be assessed and taken into account in the MSP processes. In a course of implementation of the INTERREG BSR Baltic LINes project, this planning issue is addressed by analysis of the potential impact on navigational safety from planned OREI off the Hiiumaa Island (Estonia) in the Baltic Sea. As a result, the safe distance of turbines' boundary from shipping route is evaluated referring as an example to UK relevant regulations determining the manoeuvring space that vessels need in order to keep a safe distance from multiple structures such as OREI. Accompanying environmental safety issues related to marine space allocation for OREI developments off the Hiiumaa Island are addressed.
\end{abstract}

\section{Introduction}

Human activities in marine areas are increasing in numbers and intensity, with the patterns of sea use changing as a result of political, economic, and societal developments. The Integrated Maritime Policy for the EU [1] identifies Maritime Spatial Planning (MSP) as a cross-cutting policy tool enabling public authorities and stakeholders to apply a coordinated, integrated and trans-boundary approach. According to EU Directive establishing a framework for Maritime Spatial Planning (MSP) [2], the main purpose of MSP is to promote sustainable development and to identify the utilization of maritime space for different sea uses as well as to manage spatial uses and conflicts in marine areas. The offshore wind energy production is considered to be one of the main drivers of MSP in the Baltic Sea Region.

It is stated [3] that there are some issues of critical importance to be considered by shipping industry when engaging in an MSP process: 1) when considering the rerouting of shipping lanes or the placement of MSP limitations on sea space (e.g., aquaculture and offshore energy installations) the manoeuvring characteristics of vessels must be considered both for normal and abnormal conditions, 2) the constraint should be observed so that four *Corresponding author: robert.aps@ut.ee 
ships should safely be able to pass each other in a shipping lane and a distance between overtaking and meeting vessels of two ship's lengths should be normally maintained as a minimum passing distance, 3) anything that might obscure visibility or radar conspicuity (i.e. a physical object, electronic interference or even light pollution, either at sea or on the shoreline) must be taken into account when assessing the impact on shipping by other marine users under an MSP plan, 4) enforcement of isolation zones for different ocean users such as commercial shipping, fishing and leisure craft in cases of increased traffic density in increasingly constricted water space, 5) in addition to navigational safety risks, assessment of the impact rerouting may have on the environment and commercial operations.

A System Theoretic Accident Modelling and Processes (STAMP) approach was originally developed for software and space engineering applications [4]. STAMP considers accident occurrence as the result of a lack of, or inadequate enforcement of, constraints imposed on the system design and operations at various system levels. The STAMP methodology has been used to map the hierarchical regulatory levels - from global to local of the maritime transportation and environment safety management system [5]. The STAMP-Mar approach is recommended as a basis for safety management of a sustainable eco-socio-technical maritime transportation system [6]. The STAMP based Systems Theoretic Process Analysis (STPA) [4, 7] as a powerful new hazard analysis method has been successfully applied e.g. to space engineering applications [8] as well as to analysis of maritime traffic safety in the Gulf of Finland [9].

In a course of implementation of the INTERREG BSR Baltic LINes project the impact on navigational safety from offshore renewable energy installations (OREI) is identified as one of the critical transnational and cross sectoral planning issues. This planning issue is addressed by analysis of the potential impact on navigational safety from planned OREI off the Hiiumaa Island in the Baltic Sea.

The UK OREIs related safety of navigation guidance requirements [10] based STPA hazard analysis is applied to identify the system level hazards related to planned OREI areas, corresponding safety constraints and the potentially unsafe control actions that may lead to hazardous allocation of OREIs areas.

\section{Assessing safe distances between OREI boundaries and shipping routes}

Marine navigation safety issues within and close to OREI exist in many situations, and particularly where there is a combination of high traffic levels, different vessel operations and constrained water spaces. Referring to [10] the following factors should be evaluated and taken into account: 1) concentrations of fishing vessels, or leisure traffic, will create requirements for manoeuvre and course alteration by other through traffic and also restrict sea room in the shipping lane consequently increasing the risk of further vessel to vessel conflict, 2) displacing a group of traffic into space utilised by other users where available sea room is already confined and especially where leisure traffic is forced to use the same sea space as much larger and faster commercial vessels, 3) the existence of submarine cables or other seabed obstructions may affect the ability of a vessel to anchor safely away from other traffic and this may be another consideration when assessing sea room requirements, and 4) dependant on the proximity to wind turbine towers, and the location of radar scanners aboard the vessel, some vessels may experience degradation of the radar display by false echoes reducing the ability of the bridge team to identify other vessels, including crossing vessels at the extremities of the lanes, which may require avoiding action. 


\subsection{The planning issue}

The planned OREI sea areas off the Hiiumaa Island (Estonia) in the Baltic Sea are crossed with intensive maritime traffic according to the Automatic Identification System (AIS) based maritime traffic visualization (Figure 1). This spatial overlap is creating the critical transnational and cross sectoral planning issue that needs to be resolved before the actual implementation of OREI in this sea area.

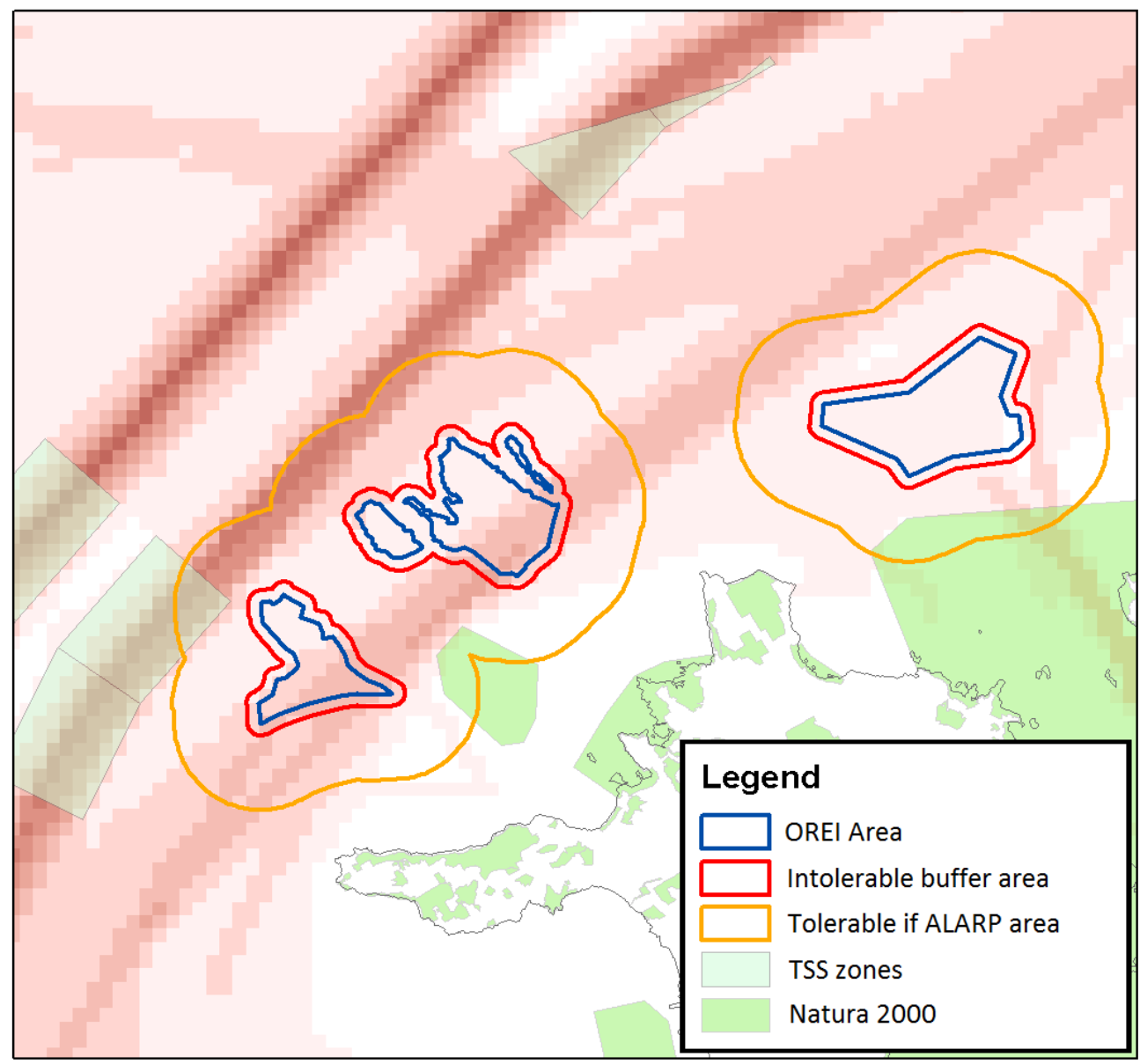

Fig. 1. Planned OREI sea areas off the Hiiumaa Island (Estonia) in the Baltic Sea are crossed by intensive maritime traffic (source - HELCOM Secretariat, based on HELCOM AIS data).

As an example, the possible practical solution to the planning issue presented in Figure 1 can be based on the UK OREIs related safety of navigation guidance [10] requirements. In Hiiumaa case the OREIs safety buffer areas design is not meeting these guidance requirements and is identified as the system-level hazard. Further, the guidance related OREIs buffer areas design safety criteria are considered as the system safety constraints to be imposed on the OREIs buffer areas design. 
According to UK OREIs related safety of navigation guidance [10] requirements if the distance of turbine boundary from shipping route 1) is less than $<0.5 \mathrm{~nm}(<926 \mathrm{~m})-$ intolerable (red on Figure 1), 2) is between $0.5 \mathrm{~nm}-3.5 \mathrm{~nm}(926 \mathrm{~m}-6482 \mathrm{~m})$ - tolerable (yellow on Figure 1) if the risk is being reduced to as low as reasonably practicable (ALARP) - additional risk assessment and proposed mitigation measures required, and 3 ) is more than $>3.5 \mathrm{~nm}(>6482 \mathrm{~m})-$ broadly acceptable.

\subsection{STPA hazard analysis}

The OREIs safety buffer areas design related system-level hazards and safety constraints to be enforced are presented in Table 1.

Table 1. The OREIs safety buffer areas design related system-level hazards and safety constraints.

\begin{tabular}{|l|l|}
\hline $\begin{array}{l}\text { System level hazards related to } \\
\text { OREIs safety buffer areas } \\
\text { design }\end{array}$ & $\begin{array}{l}\text { OREIs safety buffer areas design safety constraints } \\
\text { according to UK OREIs related safety of navigation } \\
\text { guidance requirements }\end{array}$ \\
\hline $\begin{array}{l}\text { OREIs safety buffer areas design } \\
\text { is not meeting the UK OREIs } \\
\text { related safety of navigation } \\
\text { guidance requirements }\end{array}$ & $\begin{array}{l}\text { The distance of turbine boundary from shipping route 1) is } \\
\text { less than }<0.5 \mathrm{~nm}(<926 \mathrm{~m})-\text { intolerable, } 2) \text { is between } 0.5 \mathrm{~nm} \\
-3.5 \mathrm{~nm}(926 \mathrm{~m}-6482 \mathrm{~m})-\text { tolerable if the risk is being } \\
\text { reduced to as low as reasonably practicable (ALARP) - } \\
\text { additional risk assessment and proposed mitigation measures } \\
\text { required, and 3) is more than }>3.5 \mathrm{~nm}(>6482 \mathrm{~m})-\text { broadly } \\
\text { acceptable. }\end{array}$ \\
\hline
\end{tabular}

As the first step of STPA, the potentially unsafe design control actions that may lead to hazardous design of OREIs safety buffer areas are identified and presented in Table 2.

Table 2. Potentially unsafe OREIs safety buffer areas design control actions that may lead to the OREIs safety buffer areas hazardous design.

\begin{tabular}{|c|c|c|c|}
\hline $\begin{array}{c}\text { Control action } \\
\text { required }\end{array}$ & $\begin{array}{c}\text { Action required but } \\
\text { not provided }\end{array}$ & $\begin{array}{c}\text { Action provided } \\
\text { unsafe }\end{array}$ & $\begin{array}{c}\text { Action provided too } \\
\text { late }\end{array}$ \\
\hline $\begin{array}{c}\text { Impose OREIs safety } \\
\text { buffer areas design } \\
\text { constraints according } \\
\text { to UK OREIs related } \\
\text { safety of navigation } \\
\text { guidance }\end{array}$ & $\begin{array}{c}\text { Hazardous design }- \\
\text { OREIs safety buffer } \\
\text { areas design } \\
\text { constraints according } \\
\text { to UK OREIs related } \\
\text { safety of navigation } \\
\text { guidance requirements } \\
\text { are not imposed }\end{array}$ & $\begin{array}{c}\text { Hazardous design - } \\
\text { OREIs safety buffer } \\
\text { areas design } \\
\text { constraints according } \\
\text { to UK OREIs related } \\
\text { safety of navigation } \\
\text { guidance requirements } \\
\text { are not properly } \\
\text { imposed }\end{array}$ & $\begin{array}{c}\text { Hazardous design }- \\
\text { OREIs safety buffer } \\
\text { areas design } \\
\text { constraints according } \\
\text { to UK OREIs related } \\
\text { safety of navigation } \\
\text { guidance requirements } \\
\text { are imposed too late }\end{array}$ \\
\hline
\end{tabular}

The second step of STPA hazard analysis is performed based on expert opinions to identify the causal factors for potentially unsafe control actions. With the aim to avoid potentially unsafe OREIs safety buffer areas design flaws the implementation of safety-guided design is suggested. It is suggested also to use STPA in a proactive way by integrating the design and hazard analysis into the safety-guided design processes from the very beginning.

In a case that the Hiiumaa Island OREIs safety buffer areas will be designed according to UK OREIs related safety of navigation guidance requirements the special attention should be paid to the critical consequences for the maritime traffic management - the unavoidable 
displacement of a group of traffic into space utilised by other users where available sea room is already confined and especially where leisure traffic is forced to use the same sea space as much larger and faster commercial vessels. Further, concentrations of fishing vessels and/or leisure traffic, will create requirements for manoeuvre and course alteration by other through traffic and also restrict sea room in the shipping lane consequently increasing the risk of further vessel to vessel conflict.

\subsection{Environmental safety}

The environmental background of the planned OREIs sea areas off the Hiiumaa Island in the Baltic Sea is characterized by high and sensitive benthic biodiversity (Figure 2).

Biodiversity enhances the efficiency by which ecological communities capture resources, produce biomass, maintain water properties [11] and recycle nutrients [12]. In addition, it increases the stability of ecosystem processes through time $[13,14]$ and is vitally important for maintaining ecosystem integrity and sustainability $[15,16]$.

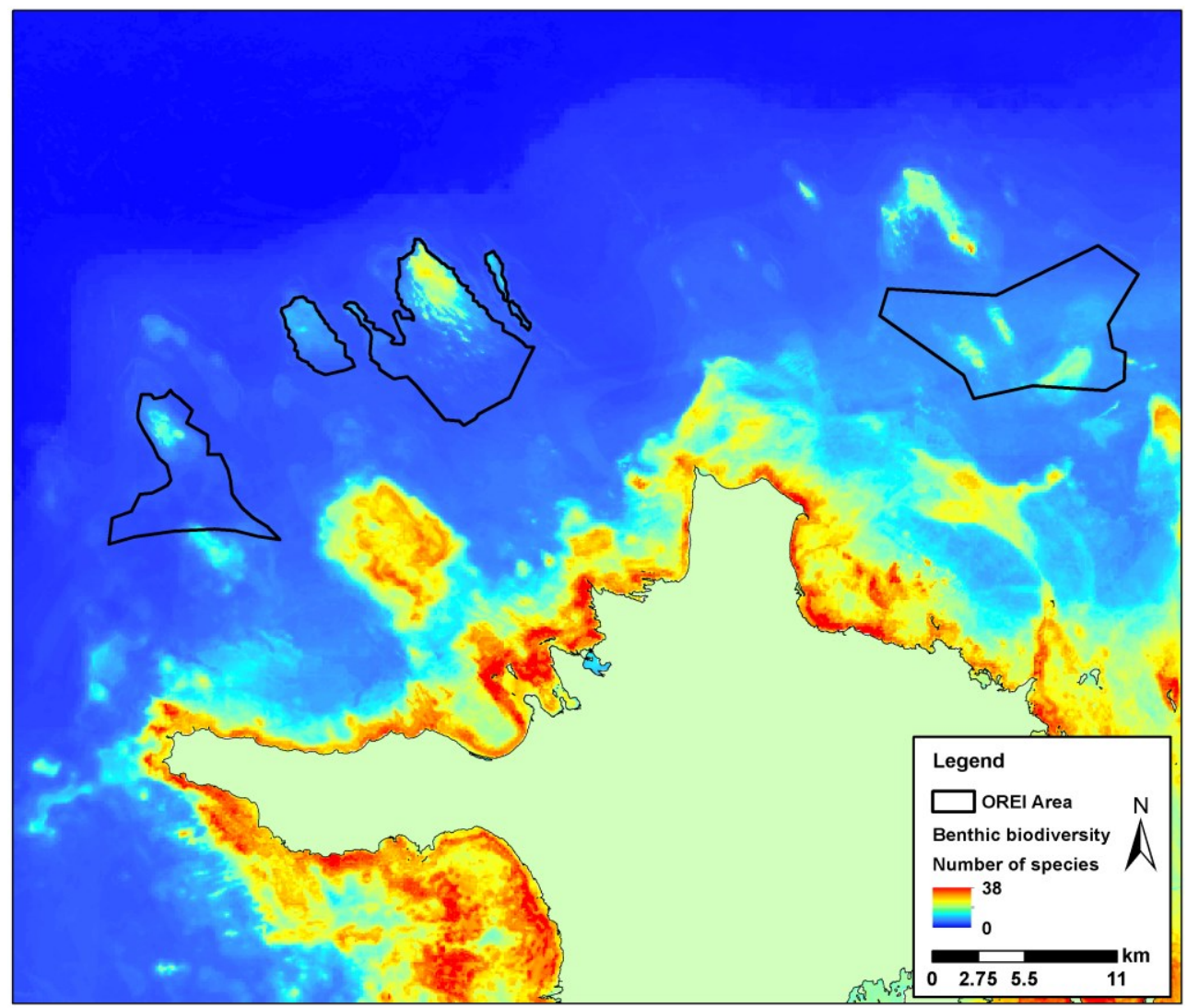

Fig. 2. Benthic biodiversity spatial distribution related to planned OREIs sea area off the Hiiumaa Island (Estonia) in the Baltic Sea.

As an example, referring to diverse and sensitive environmental background of the Hiiumaa Island planned OREIs sea area the main environmental safety requirement is that the design 
should satisfy, the UK OREIs related safety of navigation guidance requirements. However, spatial attention should be paid to environmental risk management caused by unavoidable displacement of a group of traffic into space utilised by other users where available sea room is already confined. It is also stated [10] that where larger developments have to provide corridors between sites to allow safe passage of shipping a detailed assessment will be required to establish the minimum width of the corridor.

According to IMO [17] in planning to establish multiple structures at sea, including but not limited to wind turbines "Governments should take into account, as far as practicable, the impact these could have on the safety of navigation, including any radar interference. Traffic density and prognoses, the presence or establishment of routeing measures in the area, and the manoeuvrability of ships and their obligations under the 1972 Collision Regulations should be considered when planning to establish multiple structures at sea. Sufficient manoeuvring space extending beyond the side borders of traffic separation schemes should be provided to allow evasive manoeuvres and contingency planning by ships making use of routeing measures in the vicinity of multiple structure areas".

The MSP is becoming an increasingly important tool for adaptive safety management of maritime transportation being ecosystem-based, integrated, place-based or area-based, adaptive, strategic, anticipatory and participatory iterative process [3]. Thereby, the objective is to integrate the issues that are most vital to maritime transportation - safety, continued operation, business success and efficiency of sustainable maritime transportation system into the MSP options.

\section{Conclusions}

To avoid potentially unsafe OREIs safety buffer areas design flaws the implementation of safety-guided design is suggested with the aim to embed the cost-effective safety effort into the OREIs safety buffer areas design processes from the very beginning and to design safety into the system as the design decisions are made.

It is suggested to use STPA in a proactive way guiding OREIs safety buffer areas design by integrating the design and hazard analysis into the safety guided design processes. As a result, it is expected that the OREIs safety buffer areas design safety constraints will be satisfied in a course of ecosystem based development and implementation of the integrated transboundary MSP solutions.

Spatial attention should be paid to efficiency of environmental risk management related to unavoidable displacement of a group of traffic into space utilised by other users where available sea room is already confined and risk of further vessel to vessel conflict is increased.

\section{Acknowledgements}

Authors would like to offer special thanks to Manuel Frias Vega and Florent Nicolas from HELCOM Secretariat for providing the HELCOM AIS data used by this study.

This study is supported by European Regional Development Fund, INTERREG Baltic Sea Region project Baltic LINes "Coherent Linear Infrastructures in Baltic Maritime Spatial Plans". 


\section{References}

1. EC, Directive 2008/56/EC of the European Parliament and of the Council of 17 June 2008 establishing a framework for community action in the field of marine environmental policy - Marine Strategy Framework Directive (2008)

2. EC, Establishing a Framework for Maritime Spatial Planning, Directive 2014/89/EU, European Council, Brussels (2014)

3. D. Patraiko and P. Holthus, The shipping industry and marine spatial planning - a professional approach. The Nautical Institute and the World Ocean Council (2013)

4. N. Leveson, Engineering a safer world - systems theory applied to safety, Cambridge, MA, MIT Press (2011)

5. R. Aps, M. Fetissov, F. Goerlandt, J. Helferich, M. Kopti and P. Kujala, Towards STAMP based dynamic safety management of eco-socio-technical maritime transport system, Procedia Engineering, 128 (2015)

6. R. Aps, M. Fetissov, F. Goerlandt, M. Kopti and P. Kujala, STAMP-Mar based safety management of maritime navigation in the Gulf of Finland (Baltic Sea), European Navigation Conference 2016, Helsinki, 30 May-2 June 2016, IEEE Xplore (2016

7. J.P. Thomas, Extending and Automating a Systems-Theoretic Hazard Analysis for Requirements Generation and Analysis, Sandia Report SAND2012-4080, Sandia National Laboratories (2012)

8. T. Ishimatsu, N. Leveson, J. Thomas, C. Fleming, M. Katahira, Y. Miyamoto, R. Ujiie, H. Nakao, N. Hoshino, Hazard Analysis of Complex Spacecraft Using SystemsTheoretic Process Analysis, Journal of Spacecraft and Rockets, 51 (2) (2014)

9. R. Aps, M. Fetissov, F. Goerlandt, P. Kujala, A. Piel, Systems-Theoretic Process Analysis of maritime traffic safety management in the Gulf of Finland (Baltic Sea), Procedia Engineering, 179, Elsevier (2017)

10. MCA, Offshore Renewable Energy Installations (OREIs) - Guidance on UK Navigational Practice, Safety and Emergency Response Issues, MGN 371 (M+F) (2016)

11. B. Worm, EB. Barbier, N. Beaumont, JE. Duffy, C. Folke and BS. Halpern, Impacts of Biodiversity Loss on Ocean Ecosystem Services. Science 314 (2006)

12. BJ. Cardinale, JE. Duffy, A. Gonzalez, DU. Hooper, C. Perrings, P. Venail et al Biodiversity loss and its impact on humanity. Nature 486 (2012)

13. D. Tilman, PB. Reich and JMH. Knops, Biodiversity and ecosystem stability in a decade-long grassland experiment. Nature 441(2006)

14. V. Campbell, G. Murphy and TN. Romanuk, Experimental design and the outcome and interpretation of diversity-stability relations. Oikos 120 (2011)

15. DU. Hooper, FS. Chapin, JJ. Ewel, A. Hector, P. Inchausti et al, Effects of biodiversity on ecosystem functioning: a consensus of current knowledge. Ecol. Monograph $\mathbf{7 5}$ (2005)

16. F. Boero and E. Bonsdorff, A conceptual framework from marine biodiversity and ecosystem functioning. Mar. Ecol. 28 (2007)

17. IMO, Guidance Note on the preparation of proposals on ships' routing systems and ship reporting systems, MSC/Circ.1060 (2003) 